\title{
Evaluation of constitutive models in predicting ratcheting responses of a structure under thermo-mechanical loadings - COMPLAS 2021
}

\author{
J. MACEDO ${ }^{*}, 1,2$, J. M. BERGHEAU ${ }^{2}$, E. FEULVARCH ${ }^{2}$, H. BATTIE ${ }^{1,2}$, O. \\ ANCELET $^{1}$, A. MARTIN ${ }^{1}$, STÉPHANE CHAPULIOT ${ }^{3}$ \\ ${ }^{1}$ Engineering and Design Authority Unit \\ Framatome \\ France \\ email: jean-caio.macedo-alves-de-lima1@framatome.com \\ olivier.ancelet@framatome.com/antoine.martin@framatome.com/ \\ ${ }^{2}$ Laboratoire de tribologie et dynamique des systèmes (LTDS), \\ University of Lyon, ECL, ENISE, CNRS \\ Saint-Etienne, France \\ email: jean-michel.bergheau@enise.fr/eric.feulvarch@enise.fr/hugo.battie@enise.fr \\ ${ }^{3}$ EDF Group \\ France \\ email: stephane.chapuliot@edf.fr
}

\begin{abstract}
Ratcheting is a damage mechanism that needs to be avoided to ensure the continuing integrity of structures. To this end, the use of a constitutive model is sometimes required. The objective of this paper is to evaluate the performance of three constitutive models in predicting ratcheting responses of a 316L stainless steel structure under thermo-mechanical loadings.

Firstly, the bi-tube test is described, including specimen geometry, heating system and mechanical loading. Secondly, the models proposed by Prager, Armstrong-Frederick and Chaboche are briefly recalled and a methodology to identify their parameters is presented.

Finally, a finite element model is exposed and numerical simulations are carried out in order to compare and discuss the results of the above mentioned constitutive models. Comparisons demonstrate that the best option to simulate ratcheting responses seems to be the introduction of an isotropic hardening with a plastic strain memorisation in the cyclic plasticity model. It has also observed that the ratcheting hate has to be considered during the model identification phase.
\end{abstract}

\section{REFERENCES}

[1] P. J. Armstrong et C. O. Frederick, «A Mathematical Representation of the Multiaxial Bauschinger Effect,,» Berkeley Nuclear Laboratories,1966, Reprinted in Mat. High Temp. 24, 2007, 11-26.

[2] J.-L. Chaboche, «a Review of some Plasticity and Viscoplasticity Constitutive Theories,» International Journal of Plasticity, pp. 1642-1693, 2008.

[3] W. Prager, «Recent Developments in the Mathematical Theory of Plasticity,» Journal of Applied Physics, p. 235, 1949.

[4] J. Macedo, S. Chapuliot, J. M. Bergheau, E. Feulvarch, O. Ancelet et A. Martin, «A historical review of design analyses and experimental observations of ratcheting phenomenon,» Pressure Vessels \& Piping Conference, 19-24 Juillet 2020.

[5] J. M. Bergheau et R. Fortunier, Finite Element Simulation of Heat Transfer, France, 2004. 